\title{
The Melanesian Media Declaration
}

We, the participants at the Melanesian Media Freedom representing media from Fiji, Vanuatu, Solomon Islands, Papua New Guinea and West Papua, wish to express concern about growing threats to media freedom in our region and call on members of our industry and other organisations and individuals to take action to help secure the future of the Fourth Estate as a vital pillar of democracy.

Professional media, through accurate and impartial reporting has a crucial role to play. As António Guterres, United Nations Secretary-General, said on World Press Freedom Day 2019:

No democracy is complete without access to transparent and reliable information. It is the cornerstone for building fair and impartial institutions, holding leaders accountable and speaking truth to power.

We note that Article 19 of the Universal Declaration of Human Rights states: 'Everyone has the right to freedom of opinion and expression; this right includes freedom to hold opinions without interference and to seek, receive and impart information and ideas through any media and regardless of frontiers.'

\section{In this context we observe that}

- A better understanding is needed of the role of journalism in Melanesian democracies. Awareness of the accountability role played by journalists and the need for them to be able to exercise their professional skills without fear is critical to the functioning of our democracies.

- The media is ready to work with all parties that want to improve the social media landscape: There is an urgent need for the media to assert its role as a source of accurate and impartial information and to play a role in building social media literacy and public understanding of how to identify credible sources of information.

We express concern that

- The range of threats to media freedom is increasing. These include restrictive legislation, intimidation, political threats, legal threats and prosecutions, assaults and police and military brutality, illegal detention, online abuse, racism between ethnic groups and the ever-present threats facing particularly younger and female reporters who may face violence both on the job and within their own homes.

- Threats to media freedom are having professional, personal and health impacts on journalists across Melanesia. The situation in West Papua is of particular concern with attacks on journalists resulting in deaths and injuries.

- The unwillingness of politicians and officials to engage in dialogue is undermining the media's accountability role: public figures are becoming more resistant to responding to direct questions from media, choosing 
instead to issue media releases, or statements on social media or to preferred media outlets. In addition to undermining the crucial accountability role of the media, this places broadcast media (which requires actuality) at a disadvantage.

- Obstruction from development partners and communications consultants, including from Australia, are in some instances contributing to problems of lack of access to decision-makers.

- The global decline of democracy is making it easier for our governments to silence the media. It is expected this will become a bigger challenge in the future if it is not addressed, as national leaders, media organisations and journalists come under pressure and misinformation campaigns continue.

- Misinformation, propaganda and fake news are a growing problem: there is widespread concern around misinformation and offensive material being posted on social media platforms, sometimes by anonymous sources, some of them state and politically-partisan actors. The media's role as an antidote, and as a balancing source of verified information is under-recognised and under-supported.

- Social media is an existential threat undermining Melanesian media companies: the erosion of editorial budgets and vulnerability of the mainstream media's business model to the flight of advertising revenue and audiences to social media is an urgent threat to media throughout Melanesia and therefore to media freedom.

- Significant sections of the population in some Melanesian countries do not have access to information services. This undermines the media's role in providing access to information and debate. Some media organisations, including public broadcasters, lack the basic equipment needed to do their job properly.

- Women in the media face additional challenges. Women are underrepresented in many newsrooms and in media management. They can face additional challenges in being recognised and responded to by people in authority and they face threats to their safety including sexual harassment, gender-based violence and expectations from partners and family.

We applaud

- The invaluable work of National Media Organisations, the Pacific Islands News Association (PINA), the Pacific Freedom Forum (PFF), and the Pacific Media Watch Freedom Project (based at AUT's Pacific Media Centre) in defending media freedom (including at IFEX).

\section{Recommendations:}

We call on Melanesian governments to

- Respect the media and its necessary place in national conversations. 
- Require political leaders and senior public servants make themselves available for interviews with their local media.

- Recognise, respect and support National Media Associations as the voice of the media industry.

- Fund public broadcasters properly to ensure they have sufficient equipment and staff to enable their services to reach all citizens in their country and to adequately play their watch-dog role.

-Assure the safety of journalists as they pursue their professional activities.

We call on the Papua New Guinea government to

- Respect the independence of media institutions and journalists.

- Strengthen anti-corruption and whistle-blower protection legislation to include journalists and media practitioners.

We call on civic institutions in Bougainville to

- Respect and respond promptly to requests for information at this crucial time.

Melanesia Media Freedom Forum

11-12 November 2019

Griffith University, Southbank, Brisbane

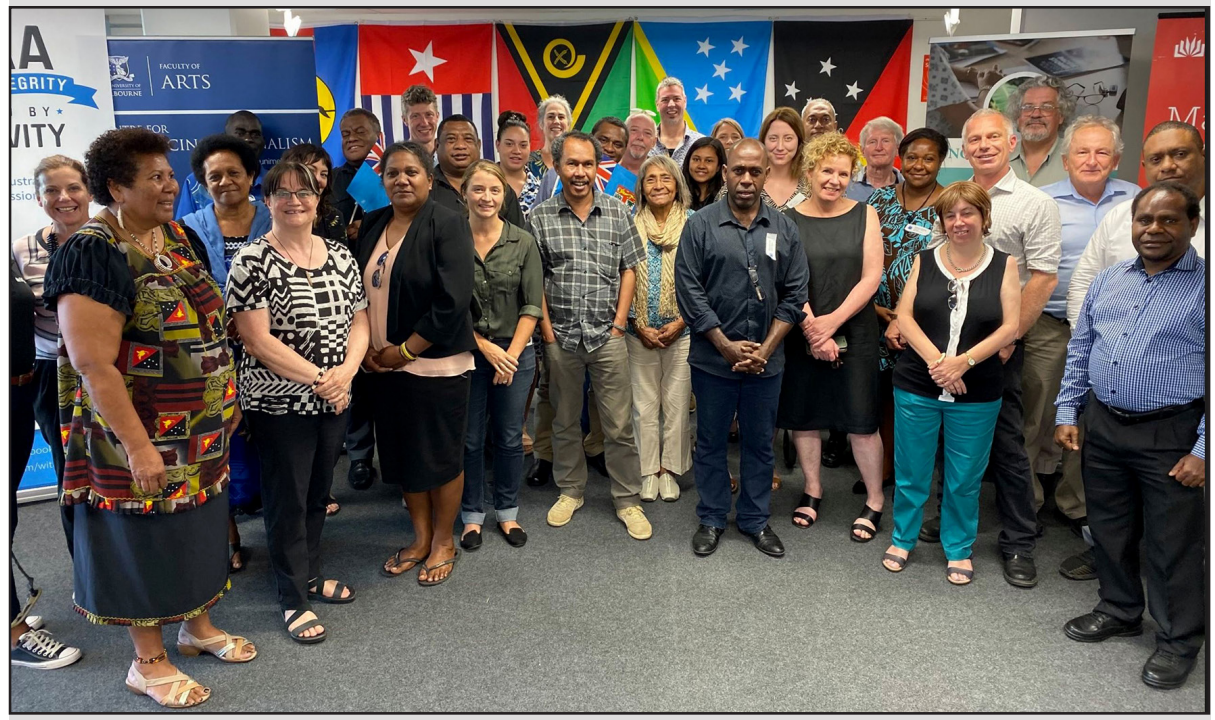

Figure 1: Participants at the Melanesia Media Freedom Forum (MMFF) symposium in Brisbane, Queensland, on 11-12 November 2020. 


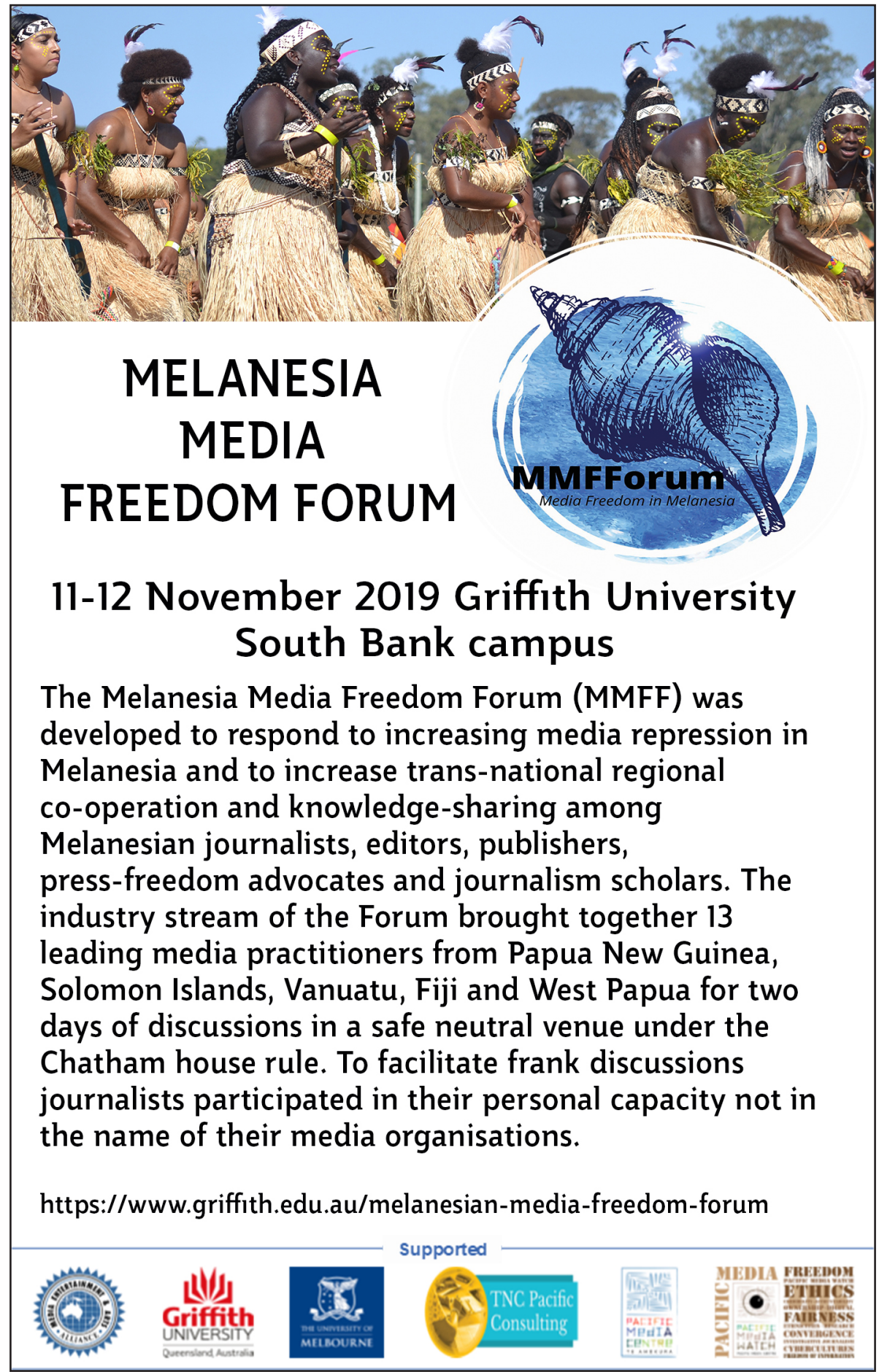

